\title{
Aggression level and enclosure size in horses (Equus caballus)
}

\author{
Birgit Flauger ${ }^{7}$ and Konstanze Krueger ${ }^{2}$
}

Biology I, Institute of Zoology, University of Regensburg, Regensburg ${ }^{1}$ and Agriculture, Economics and Management, Department Equine Economics, Nuertingen Geislingen University, Nuertingen², Germany

\begin{abstract}
Summary
Even though animal welfare organisations propose group housing for horse welfare, many owners stable horses individually for fear of aggressive interactions and injury risks. In the present study we observed social behaviour, and especially aggressiveness, in eleven domestic horse groups (Equus caballus) of different size and composition, in basic social situations and when new group members were introduced. During basic social situations, the group and the type of paddock (grass/no grass) had no effect on any of the behaviours, whereas the enclosure size below $10,000 \mathrm{~m}^{2}$ had a significant effect on submissive behaviour $(G z L M ; n=56 ; \dagger=-2.061, P=0.044)$ and an insignificant effect on aggressive behaviour $(G z L M ; n=56 ; t=-1.782, P=0.081)$. However, aggressive and submissive behaviour diminished with the increase of enclosure sizes up to 10,000 $\mathrm{m}^{2}$ (Spearman rank correlation; $n=56$; aggressive behaviour: $r=-0.313$, $P=0.019$; submissive behaviour: $r=-0.328, P=0.014)$. During introductions, aggression levels per hour decreased with any increase of enclosure size (Spearman rank correlation; $\mathrm{n}=28 ; \mathrm{r}=-0.402, \mathrm{P}=0.034$ ) and even more when enclosure sizes above $10,000 \mathrm{~m}^{2}$ were excluded (Spearman rank correlation; $n=23 ; r=-0.549, P=0.007$ ). During basic social situations the aggression level approached zero when the space allowance was more than $331 \mathrm{~m}^{2}$ per horse. We therefore recommend keeping horse groups in an enclosure with at least $331 \mathrm{~m}^{2}$ per horse to reduce aggression and injuries.
\end{abstract}

Keywords: aggression / injury risk / social behaviour / group housing / horse management / introduction of horses

\begin{abstract}
Aggressionslevel und Platzangebot bei Pferden (Equus caballus)
Viele Pferdebesitzer bevorzugen aus Angst vor aggressiven Interaktionen und Verletzungsgefahr der Tiere untereinander die Einzelhaltung, obwohl von Tierschutzorganisationen die Gruppenhaltung für Pferde empfohlen wird. In dieser Studie beobachteten wir während des alltäglichen Soziallebens als auch bei der Eingliederung von neven Gruppenmitgliedern das Sozialverhalten, insbesondere das Aggressionsverhalten, von elf Gruppen domestizierter Pferde (Equus caballus) verschiedener Größe und Zusammensetzung. Während des alltäglichen Soziallebens hatten die Gruppe und der Paddock-Typ (Gras/kein Gras) keinen Einfluss auf die Verhaltensweisen, wohingegen die Paddockgröße unter $10000 \mathrm{~m}^{2}$ einen signifikanten Einfluss auf die submissiven Verhaltensweisen ( $\left.\mathrm{GL} L \mathrm{M} ; \mathrm{n}=56 ; \dagger=-2.061, \mathrm{P}=0.044\right)$ und einen nicht signifikanten Einfluss auf die aggressiven Verhaltensweisen ( $\mathrm{zz} L \mathrm{M} ; \mathrm{n}=56 ; t=-1.782, \mathrm{P}=0.081$ ) hatte. Allerdings verringerten sich sowohl die aggressiven als auch die submissiven Verhaltensweisen mit steigendem Platzangebot bis zu $10000 \mathrm{~m}^{2}$ (Spearman rank Korrelation; $n=56$; aggressive Verhaltensweisen: $r=-0.313, P=0.019$; submissive Verhaltensweisen: $r=-0.328, P=0.014)$. Während den Eingliederungen reduzierten sich die Aggressionen pro Stunde mit der Vergrößerung des Platzangebotes (Spearman rank Korrelation; $\mathrm{n}=28$; $r=-0.402, P=0.034)$. Dies zeigte sich noch deutlicher, wenn Beobachtungen mit einem Platzangebot von über $10000 \mathrm{~m}^{2}$ ausgeschlos sen wurden (Spearman rank Korrelation; $n=23 ; r=-0.549, P=0.007$ ). Während des alltäglichen Soziallebens näherte sich der Aggressionslevel der Nulllinie an, wenn das Platzangebot pro Pferd mehr als $331 \mathrm{~m}^{2}$ betrug. Deshalb empfehlen wir zur Reduzierung des Aggressionslevels und des Verletzungsrisikos von sozial gehaltenen Pferdegruppen ein Platzangebot von mindestens $331 \mathrm{~m}^{2}$ pro Pferd.
\end{abstract}

Schlüsselwörter: Aggression / Verletzungsgefahr / Sozialverhalten / Gruppenhaltung / Pferdehaltung / Eingliederung von Pferden

\section{Introduction}

Animals housed under human supervision usually have to deal with limited space. When kept in social groups in unsuitably small enclosures, there may be enhanced aggression levels amongst animals because their need for individual space in terms of a minimum distance between conspecifics cannot be satisfied (Wilson 2000). In fact, reduced space for animals can be directly linked to a more aggressive behaviour in cattle (Kondo et al. 1989), pigs (Weng et al. 1998), dama gazelle (Cassinello and Pieters 2000), deer (Li et al. 2007), and horses (e.g. Skiff 1982, Hogan et al. 1988, Jørgensen et al. 2009). Menke et al. (1999) demonstrated that agonistic behaviour increases continuously when the space per animal decreases in cows.

In horses, it is largely unknown whether aggressive behaviour and space allowances per animal are a function of continu- ous dependency, and which factors might have an effect on aggressiveness among group members. The horse is a highly social species: given the opportunity, under semi-natural conditions, domestic horses gather in social groups. They form bachelor stallion groups and harem groups that usually consist of one to three stallions, several mares and their offspring (Feist and McCullough 1975, Berger 1977). Even though core groups are considerably stable, horses can be said to live in fission-fusion systems (Dyer 2000) in which animals split and reunite again, as observed in apes (Dyer 2000), elephants (Moss and Poole 1983) and dolphins (Connor et al. 2000). Offspring disperse from the natal groups at the age of about one to five years, with an average age of two years (Rutberg and Keiper 1993, Monard et al. 1996, Kaseda et al. 1997), and build new groups or join established harems or bachelor groups. Furthermore, harem and band stability varies considerably between groups and populations 
(Berger 1986, Rubenstein 1986, Rutberg 1990) and mature animals were reported to join new groups repeatedly (Linklater 1998, Feh 1999).

Under domestic conditions, horses do not have the opportunity to choose their group affiliation themselves. Some are singly stabled and/or grouped artificially, which both may cause problems. When singly stabled, social isolation implicates welfare problems for a gregarious animal such as the horse, and may result in behavioural disorders or redirected behaviour towards less suitable objects such as flank biting (Luescher et al. 1991). This is why organisations such as the German "Bundesministerium für Ernährung, Landwirtschaft und Verbraucherschutz" (BMELV 2009) propose group housing for assuring horse welfare. However, when horses are stabled in groups, many owners are afraid of either the horses or persons getting injured, which may mainly occur when unfamiliar individuals are mixed (e.g. Jørgensen et al. 2009, Hartmann et al. 2011) and when horses are removed from the groups (Hartmann et al. 2012a). Bite and kick injuries were reported to be more frequent on pasture, although they may occur in any situation where horses get in contact with each other, e.g. during transportation or in the riding arenas
(Derungs et al. 2004). In fact, the occurrence of play fighting is one of the main reasons why domestic horses are kept in physical separation (Christensen et al. 2002). However, feral horses (e.g. Waring 1983) and semi-feral group housed domestic ponies (Grogan and McDonnell 2005) rarely hurt each other seriously in real combat. Instead, data demonstrate that socially reared and kept horses learn training tasks quicker than those housed in individual stalls (Rivera et al. 2002, Søndergaard and Ladewig 2004). They are also calmer, and therefore safer to handle and ride (Ladewig 2011).

According to recent reviews on group housing of horses many questions still need to be answered (Fureix et al. 2012, Hartmann et al. 2012b), such as the causality of injuries. With more conclusive data veterinarians, scientists and constructors of equine facilities could advise horse and stable owners on how to reduce injury risks in group management much better. Jørgensen et al. (2009) stated that gender composition, i.e. mares, geldings or mixed groups, is not decisive for the aggression level or injury frequency within a group. It appears as if the horse's early social experiences (Christensen et al. 2002), its space allowance, and the feeding management are more important for the successful group housing of

Tab. 1 Information on horse groups, enclosure sizes and husbandry conditions. Enclosure sizes above 10,000 square meters are depicted in bold / Informationen zu Pferdegruppen, Platzangebot und Haltungsbedingungen. Ein Platzangebot über $10000 \mathrm{~m}^{2}$ ist fett hervorgehoben

\begin{tabular}{|c|c|c|c|c|c|c|c|c|}
\hline Group & $\begin{array}{l}\text { Nr horses } \\
\text { (Min/Max) }\end{array}$ & Sexes & $\begin{array}{l}\text { Age (years) } \\
\text { (Min/Max) }\end{array}$ & $\begin{array}{l}\text { Area }\left(\mathrm{m}^{2}\right) \\
(\mathrm{g}+/ \mathrm{g}-)^{1}\end{array}$ & $\begin{array}{l}\text { Nr obser- } \\
\text { vations }\end{array}$ & $\begin{array}{l}\text { Husbandry } \\
\text { condition }\end{array}$ & $\begin{array}{l}\text { intro- } \\
\text { duction }\end{array}$ & $\begin{array}{c}\text { Area }\left(\mathrm{m}^{2}\right) \\
\text { introduction }\end{array}$ \\
\hline A & $3 / 4$ & $\begin{array}{l}\text { Mares and } \\
\text { geldings }\end{array}$ & $5 / 24$ & $\begin{array}{c}801(\mathrm{~g}-) \\
2595(\mathrm{~g}+) \\
3207(\mathrm{~g}+)\end{array}$ & $\begin{array}{c}10 \\
2 \\
1\end{array}$ & $\begin{array}{l}\text { Open stable day } \\
\text { and night }\end{array}$ & 6 & $\begin{array}{c}801(3) \\
1983 \\
3207 \\
4389\end{array}$ \\
\hline B & $4 / 5$ & Mares & $7 / 30$ & 730 (g-) & 4 & $\begin{array}{c}\text { Group housing, } \\
\text { separate boxes over } \\
\text { night }\end{array}$ & 2 & $3789(2)$ \\
\hline C & 3 & $\begin{array}{l}\text { Mares and } \\
\text { geldings }\end{array}$ & $11 / 27$ & $\begin{array}{l}4638(\mathrm{~g}+) \\
6687(\mathrm{~g}+)\end{array}$ & $\begin{array}{l}1 \\
2\end{array}$ & $\begin{array}{c}\text { Open stable day } \\
\text { and night }\end{array}$ & 1 & 4638 \\
\hline$D$ & $8 / 9$ & $\begin{array}{l}\text { Mares and } \\
\text { geldings }\end{array}$ & $4 / 20$ & $\begin{array}{c}1200(\mathrm{~g}-) \\
2160(\mathrm{~g}-) \\
12923(\mathrm{~g}+) \\
17856(\mathrm{~g}+)\end{array}$ & $\begin{array}{l}1 \\
6 \\
1 \\
1\end{array}$ & $\begin{array}{c}\text { Group housing, } \\
\text { separate boxes over } \\
\text { night }\end{array}$ & 2 & $17856(2)$ \\
\hline$E$ & $14 / 20$ & $\begin{array}{l}\text { Mares and } \\
\text { geldings }\end{array}$ & $1 / 28$ & $\begin{array}{c}1455(\mathrm{~g}-) \\
2291(\mathrm{~g}+)\end{array}$ & $\begin{array}{c}12 \\
1\end{array}$ & $\begin{array}{c}\text { Group housing, } \\
\text { separate boxes over } \\
\text { night }\end{array}$ & 6 & $\begin{array}{l}1455(3) \\
2096 \\
3718 \\
4616\end{array}$ \\
\hline $\mathrm{F}$ & $3 / 4$ & Geldings & $7 / 18$ & $\begin{array}{c}402(\mathrm{~g}-) \\
6566(\mathrm{~g}+)\end{array}$ & $\begin{array}{l}2 \\
5\end{array}$ & $\begin{array}{c}\text { Group housing, } \\
\text { separate boxes over } \\
\text { night }\end{array}$ & 4 & $\begin{array}{c}402 \\
6566(3)\end{array}$ \\
\hline G & 3 & Mares & $8 / 15$ & $\begin{array}{c}712(\mathrm{~g}-) \\
11007(\mathrm{~g}+)\end{array}$ & $\begin{array}{l}2 \\
3\end{array}$ & $\begin{array}{c}\text { Open stable day } \\
\text { and night }\end{array}$ & 2 & $\begin{array}{c}2464 \\
11007\end{array}$ \\
\hline $\mathrm{H}$ & 15 & $\begin{array}{l}\text { Mares and } \\
\text { geldings }\end{array}$ & $3 / 19$ & $\begin{array}{c}3472(\mathrm{~g}+) \\
8792(\mathrm{~g}+) \\
17882(\mathrm{~g}+)\end{array}$ & $\begin{array}{l}1 \\
1 \\
4\end{array}$ & $\begin{array}{c}\text { Open stable day } \\
\text { and night }\end{array}$ & 2 & $\begin{array}{c}3065 \\
17882\end{array}$ \\
\hline 1 & 4 & Geldings & $9 / 17$ & $\begin{array}{c}477(\mathrm{~g}-) \\
14657(\mathrm{~g}+)\end{array}$ & $\begin{array}{l}2 \\
1\end{array}$ & $\begin{array}{l}\text { Open stable day } \\
\text { and night }\end{array}$ & 1 & 14657 \\
\hline K & 8 & Geldings & $4 / 20$ & 2273 (g-) & 1 & $\begin{array}{c}\text { Group housing, } \\
\text { separate boxes over } \\
\text { night }\end{array}$ & 1 & 1576 \\
\hline$L$ & 3 & $\begin{array}{l}\text { Mares and } \\
\text { geldings }\end{array}$ & $10 / 26$ & $\begin{array}{c}1742(\mathrm{~g}-) \\
3797(\mathrm{~g}+)\end{array}$ & $\begin{array}{l}1 \\
1\end{array}$ & $\begin{array}{c}\text { Group housing, } \\
\text { separate boxes over } \\
\text { night }\end{array}$ & 1 & 3797 \\
\hline
\end{tabular}


horses (Fürst et al. 2006, Knubben et al. 2008). A stable group hierarchy and a horse-specific housing system with adequate space are important for preventing kick and bite injuries (Knubben et al. 2008). Furthermore, Fürst et al. (2006) recommend to focus on preventive measures when new horses are introduced into a group.

As studies on 'realistic' horse management instead of artificially arranged settings are urgently needed, we observed the behaviour of 11 privately owned horse groups of various size and composition. We studied them in basic social situations and when new horses were introduced. We predicted that:

1. Variables, such as the group, the type of paddock (grass/no grass), and the enclosure size may have an effect on social interactions among socially kept horses. We expected the variable enclosure size to have the strongest influence (Fürst et al. 2006, Knubben et al. 2008).

2. A clear continuous dependency between space allowance and aggressive behaviour can be shown in horses as already observed in cows (Menke et al. 1999), rather than only demonstrating low aggressiveness on large enclosures and high aggressiveness on small enclosures (e.g. Skiff 1982, Hogan et al. 1988, Jørgensen et al. 2009).

3. The enclosure size impacts social interactions both in basic social situations and when new horses are introduced (Fürst et al. 2006).

\section{Material and Methods}

Horse groups

We observed 11 different groups of horses between July 2006 and April 2009. The groups consisted of 3 to 20 horses (Mean \pm SD: 6.64 5 5.04), mares and geldings, aged between 1 and 30 years (Table 1). Throughout the study period, the groups changed in size and composition as new horses joined and resident horses left the group. The horses were of different breeds, including warmblood horses, quarter horses, trotters, Haflingers and ponies. Most of the horses were used for leisure riding, some for shows or events. The horses were housed either constantly in groups in "open stables" (i.e. stables/shelters with permanent access to paddocks and, depending on weather conditions, to additional pasture) during day and night or in groups for the day in a paddock (pasture dependent on weather conditions) and in separate boxes at night (Table 1). Sleeping areas included a bedding of straw or wood shavings. The horses received hay twice a day and a compound feed once or twice a day. Additionally, they fed on the grass in their pastures. They had free access to water.

\section{Behaviour observations}

The horse groups were initially observed for four hours and for two hours when a new horse joined the group. After six weeks, twelve weeks and one year they were observed for another two hours each. We henceforth distinguish between "basic social situations" (all observations except the introduction situation) and "introduction situation" (a new horse joi- ned the group). We ensured that all horses of the group were present during the observations, as the absence of group members would have changed the whole behaviour network of a group. Most observations were recorded in one session. During some basic social situations $(\mathrm{N}=5)$ horses were removed from the group (e.g. for riding). In these cases the observation was interrupted and continued the next day or the day after when the groups were complete again. The observations were conducted by one and the same person, who recorded all behaviour immediately. When new horses were introduced to the group, video was recorded and evaluated thereafter. Because different numbers of horses were introduced in each group, the number of observations differed between groups (on average six times, range one to 13). The various introductions will be analysed and described in detail elsewhere (Flauger and Krueger, in preparation). In the present study we focused on the relationship between space allowance and the animals' display of social behaviour in basic social and introduction situations.

Behaviour sampling (basic social situation) and focal sampling (introduction situation, focused on the interactions between new horses and group members) (Martin and Bateson 2007) were used to record the following social behaviours (modified after Feist and McCullough 1976, McDonnell and Haviland 1995, McDonnell 2003; Table 2) classified into three categories: aggressive behaviour (threat to bite, bite, threat to kick, kick, and chase), affiliative behaviour (approach), and submissive behaviour (retreat).

\section{Area}

We determined the area in which the horses were kept using the mapping programme of the Bavarian Government's "BayernViewer". It offers a tool to gauge distances and areas via aerial picture. As groups changed pastures over the different observations, for each group and for each observation the enclosure size was noted down for later analysis (Table 1). Additionally, the type of paddock (grass/no grass) was recorded.

\section{Statistical analysis}

Data was analysed with the software package IBM SPSS Statistics 19 for Windows and the R-project statistical environment (2009). To identify a mathematical formula between the enclosure size per horse and the expected aggressions per hour we analysed the data with the software program Eureqa (Schmidt and Lipson 2009).

To adjust for diverse group sizes and observation periods we divided the total number of e.g. aggressive behaviour per observation by the number of horses in the group and the duration of the observation. Thereafter, the groups' mean number of aggressive behaviour per hour and individual was used for statistical analysis. We computed selfsame affiliative behaviour, submissive behaviour, as well as total interactions (sum of aggressive, affiliative, and submissive behaviour) per hour and individual.

For comparison of the e.g. aggressive behaviour during introductions of new horses we calculated group means for the 
Table 2 Ethogram with social behaviours (modified after Feist and McCullough, 1976; McDonnell, 2003; McDonnell and Haviland, 1995) / Ethogramm mit sozialen Verhaltensweisen

\begin{tabular}{ll}
\multicolumn{1}{c}{ Behaviour } & \multicolumn{1}{c}{ Description } \\
\hline Aggressive behaviour & $\begin{array}{l}\text { Mouth open with teeth bared and ears laid back, sometimes with neck stretched toward the other horse } \\
\text { Opening and rapid closing of the jaws with the teeth grasping the flesh of the other horse. The ears are } \\
\text { Threat to bite }\end{array}$ \\
laid back and the lips retracted & $\begin{array}{l}\text { Raising the hind leg(s) slightly off the ground and under the body with tense readiness, sometimes rapidly } \\
\text { extending them backward toward another horse, but without sufficient extension or force to make contact } \\
\text { Threat to kick }\end{array}$ \\
Kick & $\begin{array}{l}\text { One or both hind legs lift off the ground and rapidly extend backwards toward another horse, with } \\
\text { One horse pursuing another, in order to displace or direct the movement of the other horse. Usually the } \\
\text { chaser has the ears laid back and exposes the teeth. The movement can be either at a walk, trot or gallop }\end{array}$ \\
Chase & $\begin{array}{l}\text { Forward movement towards another horse in a friendly way, which means that the ears are not laid back. } \\
\text { Affiliative behaviour }\end{array}$ \\
Approach & $\begin{array}{l}\text { One horse moves away in order to maintain or increase the distance. Normally retreat is a reaction in } \\
\text { response to the action of another horse }\end{array}$
\end{tabular}

aggressive behaviour per hour and the enclosure size per horse, as enclosure sizes did not differ throughout an introduction. We computed selfsame affiliative behaviour, submissive behaviour, and total interactions per hour.

We used non-parametric tests, as some data were not normally distributed according to the Kolmogorov-Smirnov test. Additionally, because standard deviations were relatively high and sample sizes low, we followed the generally accepted procedure to enhance the robustness of the non-parametric tests by applying Exact procedures. General differences in behaviour were assessed by using a Generalized Linear Model (GzLM) with the group $(1-11)$, the type of paddock (grass/no grass) and the logarithmic enclosure size $\left(\mathrm{m}^{2}\right)$ as explanatory variables. Furthermore, a Spearman rank correlation test was used to analyse the effect of enclosure size on social interactions in detail. All statistical tests were two-tailed, and alpha was set at 0.05 .

\section{Results}

General effects on social interactions in basic social situations

When analysing all basic social situations we found no significant effect of the group (1-11), type of paddock (grass/no grass) and logarithmic enclosure size $\left(\mathrm{m}^{2}\right)$ on the aggressive, affiliative, and submissive behaviour, as well as on the total interactions (GzLM; $n=66$; all $P>0.05)$.

We then excluded enclosure sizes above 10,000 square meters and found a significant effect of the logarithmic enclosure size on submissive behaviour (GzLM; $n=56$; submissive behaviour: $\mathrm{t}=-2.061, \mathrm{P}=0.044)$, and a trend on aggressive behaviour (GzLM; $n=56$; aggressive behaviour: $\dagger=-1.782, P=0.081$ ).

Therefore we continued with analysing the effect of enclosure sizes $\left(\mathrm{m}^{2}\right)$ below 10,000 square meters on the horses beha-
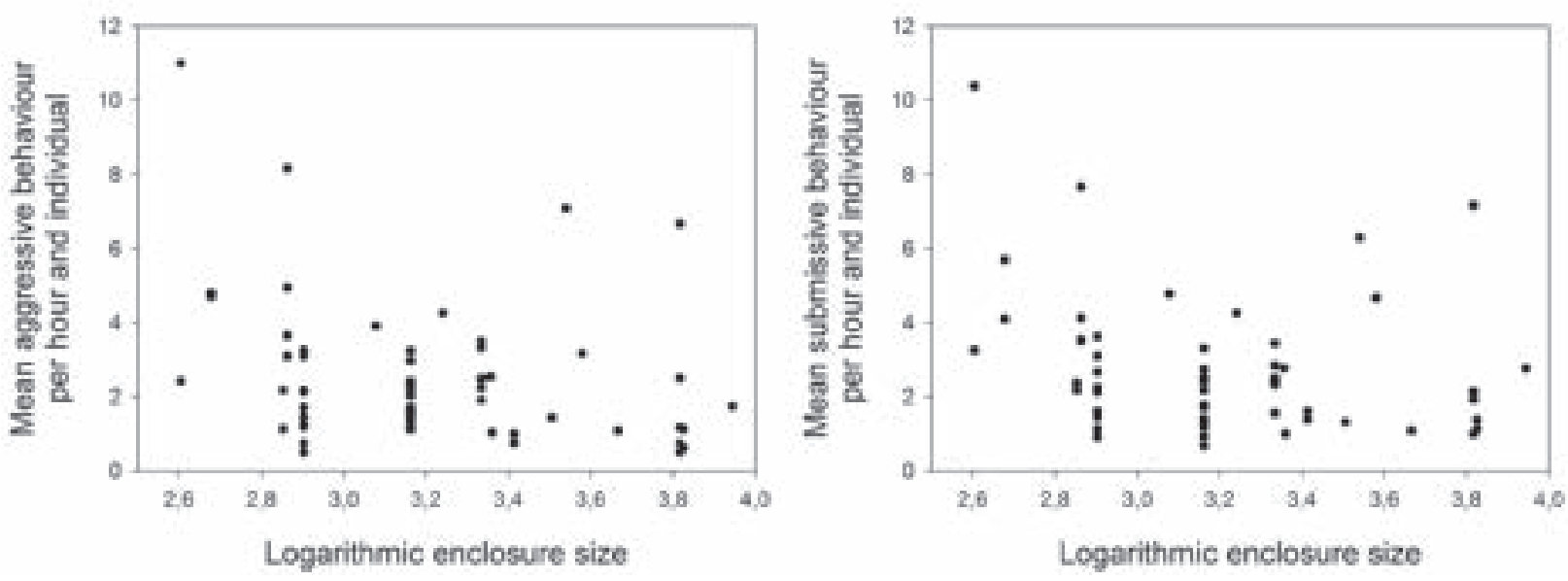

Fig. 1 Spearman rank correlation between increasing logarithmic enclosure size and a) aggressive as well as b) submissive behaviour. Spearman rank Korrelation zwischen steigendem logarithmischem Platzangebot und a) aggressiven sowie b) submissiven Verhaltensweisen. 
viour and followed the generally accepted procedure to ignore the non-significant variables group $(1-11)$ and type of paddock (grass/no grass).

\section{Effect of enclosure size on social interactions}

A significant negative correlation was found between the logarithmic enclosure size and the number of aggressive and submissive behaviours (Spearman rank correlation; $n=56$; aggressive behaviour: $r=-0.313, P=0.019$; submissive behaviour: $r=-0.328, P=0.014$; Fig. 1). The aggressive and submissive behaviours (aggressive behaviour per hour and individual: Median $=2.17$, Range $=0.50-11.00$; submissive behaviour per hour and individual: Median $=2.28$, Range $=0.67-10.38$ ), but not the affiliative behaviours and total interactions (affiliative behaviour per hour and individu-

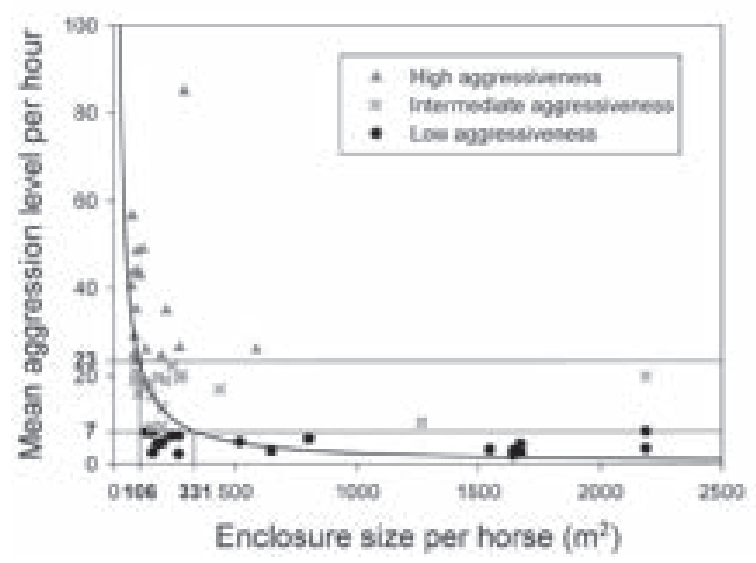

Fig. 2 Interrelation of the enclosure sizes per horse and the mean aggression levels per hour. Thin lines clarify margins between the three thirds of the horses' high, intermediate, and low aggressiveness and the corresponding enclosure sizes.

Zusammenhang zwischen Platzangebot pro Pferd und durchschnittlichem Aggressionslevel pro Stunde. Die dünnen Linien kennzeichnen die Grenzen zwischen den drei Dritteln mit hoher, mittlerer und niedriger Aggressivität der Pferde und den zugehörigen Platzangeboten.

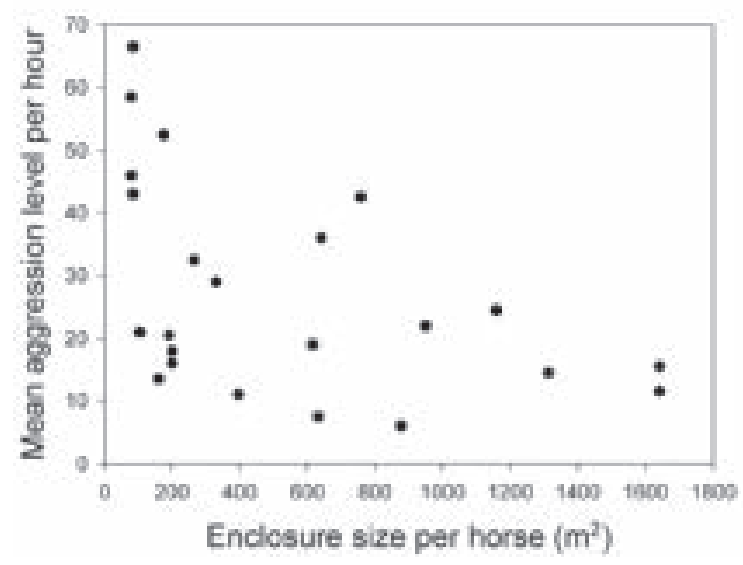

Fig. 3 Spearman rank correlation between aggressive behaviour per hour and enclosure size per horse during the introduction of new horses.

Spearman rank Korrelation zwischen aggressiven Verhaltensweisen pro Stunde und Platzangebot pro Pferd während der Eingliederung von neven Pferden. al: Median $=2.30$, Range $=0.25-7.17$; total interactions: Median $=7.76$, Range $=2.00-31.33$ ) declined with the increase of the logarithmic enclosure size.

Enclosure size per horse and mean aggression level per hour

We developed a formula which describes the interrelation of the enclosure size per horse and the aggressions horses display per hour. The curve features the characteristics of a hyperbola. The observations were split in three parts (Fig. 2): a section with relatively low aggressiveness (from 2 to 7 aggressions per hour), a section with intermediate aggressiveness (from 8 to 22 aggressions per hour) and a section with relatively high aggressiveness (from 23 to 85 aggressions per hour). The intersections between these points with the fitted curve correspond to the following enclosure sizes: less than $106 \mathrm{~m}^{2}$ per horse, $106 \mathrm{~m}^{2}-331 \mathrm{~m}^{2}$ per horse, and more than $331 \mathrm{~m}^{2}$ per horse, respectively. Based on the exponential characteristics of the curve, small changes in enclosure sizes between $0 \mathrm{~m}^{2}$ and $106 \mathrm{~m}^{2}$ trigger large increases in the aggression level among the horses. In contrast, changes above $331 \mathrm{~m}^{2}$ enclosure size per horse do not affect the aggressiveness strongly. In enclosures of more than $331 \mathrm{~m}^{2}$ per horse aggressions approach zero.

\section{Effect of enclosure size during introduction of new horses}

A significant negative correlation was found between the enclosure size per horse and the number of aggressive behaviour per hour (aggressive behaviour per hour; Medi$a_{n}=21.5$, Range $=6.0-66.5$; Spearman rank correlation; $\mathrm{n}=28 ; \mathrm{r}=-0.402, \mathrm{P}=0.034)$ when new horses joined the group. The aggressiveness during introduction situations also decreases with growing enclosure size, which is even more significant when enclosure sizes above $10,000 \mathrm{~m}^{2}$ were excluded (aggressive behaviour per hour; Median $=21.0$, Range $=6.0-66.5 ;$ Spearman rank correlation; $n=23$; $r=-0.549, P=0.007 ;$ Fig. 3). During introduction situations the correlations between enclosure size per horse and the number of affiliative and submissive behaviours per hour and the number of total interactions per hour were not significant, neither with nor without enclosures sized above 10,000 $\mathrm{m}^{2}$ (Spearman rank correlation; all P>0.05).

\section{Discussion}

In the present study we found a significant correlation between the groups' enclosure sizes and the horses' aggressive as well as submissive behaviour among group members. In basic social situations aggressive and submissive behaviours diminished with increasing logarithmic enclosure size, whereas affiliative behaviour and total interactions were not affected. When new horses joined the group the aggression level decreased with increasing enclosure size as well, but submissive behaviour was not affected.

It is interesting that correlations between aggression and logarithmic enclosure size were only found for areas below 10,000 square meters in basic social situations. In larger enclosures horses may simply maintain their individual space 
and avoid each other. Additionally, larger areas provide opportunities for splitting groups, which may be important for species that live in fission-fusion societies (Berger 1986, Rubenstein 1986, Rutberg 1990).

The authors did not find enhanced affiliative interactions when animals stayed close to each other, as reported for plains zebras (Andersen 1992). On enclosures of the sizes analysed in the present study horses stayed in sight of each other and still could have exchanged affiliative behaviour if needed, but they may protect themselves by increased aggressive interactions mainly when their personal space is invaded (Wilson 2000). It may also depend on the social relationship between two horses if a horse reacts aggressively or not, as it has been shown that only close group mates are allowed within the "personal space", whereas loosely connected social partners were tolerated only within a much larger "flight zone" (Mills and Nankervis 1999). This is supported by the observation that some groups were consistent in the numbers of displayed affiliative interactions, both, on small and large enclosures. Some groups had plenty and some had little affiliative interactions on both, small and large enclosures, even though differences between groups were not significant. Horses may have differed in the strength of their social bonds and, thus, in their numbers of displayed affiliative interactions, which will be published elsewhere (Flauger and Krueger, in prep).

The present study is the first to demonstrate a clear relationship between displayed aggressions per hour and the enclosure size per horse, which can be described by a formula showing hyperbolic characteristics. The aggressiveness among horses approaches zero when the enclosure is sized $331 \mathrm{~m}^{2}$ per horse or more. It is noteworthy that this study reveals a recommendable space allowance that is more than four times larger as the allowance mentioned in the guidelines of the German BMELV (2009) (i.e.: minimum space allowance of $150 \mathrm{~m}^{2}$ for two horses and $40 \mathrm{~m}^{2}$ for each additional horse). Swedish recommendations state $300 \mathrm{~m}^{2}$ and Danish recommendations suggest $800 \mathrm{~m}^{2}$ for individual paddock sizes (see in Jørgensen and Bøe 2007). Nevertheless, our recommendation of allowing $331 \mathrm{~m}^{2}$ per horse has to be dealt with caution, as aggression levels keep diminishing with further increase of enclosure size. This clearly demonstrates that even larger space allowances per horse are desirable for ensuring low aggression levels among horses. We also have to point at the complexity of aggressiveness among horses. In addition to space allowances, factors such as group size, group density and enclosure shape (e.g. Price and Wallach 1991, Christman and Leone 2007, Estevez et al. 2007, Leone et al. 2010), individual factors such as social experience, integration status, age and gender distribution of the group and finally, a multitude of management factors such as feeding regimes and others may affect the horses' aggressiveness and call for individual and flexible management strategies for each particular horse group (Fürst et al. 2006; see for review: Fureix et al. 2012, Hartmann et al. 2012b). However, even though the parameters mentioned above differed in the groups of the present study, the relationship between the occurrence of aggressive interactions and enclosure size was remarkably consistent between groups. Still, a minimum enclosure size of $331 \mathrm{~m}^{2}$ per horse is not a guarantee for a low aggression level, but if horses are kept on smaller enclo- sure sizes than recommended, it seems to be even more important to consider other influencing factors.

The social experience of horses is an important factor for their social tolerance. Christensen et al. (2002) demonstrated that early social experience affects aggressive behaviour when subsequently meeting unfamiliar conspecifics. In their study group stabled stallions tended to make more use of subtle agonistic interactions (displacements) whereas singly stabled stallions showed more aggressive behaviour (bite threats). Stallions displayed generally more ritual than agonistic and affiliative interactions after arranging them together as a group on pasture, and these interactions were even lower if the males had already been housed in a group in the preceding year (Briefer Freymond et al. 2013).

Furthermore, group cohesion (Waring 1983) and group stability are very important for horses. Horses have been suggested to safeguard existing social relationships and reduce the tension within horse groups by displaying third party intervention behaviour (Van Dierendonck et al. 2009, Schneider and Krueger 2012, Krueger et al. submitted) and by reconciliatory behaviour (Cozzi et al. 2010). Intervention behaviour may be more pronounced during introduction situations, as these situations lead to disturbances of the group stability as well as possible threats to social partners which have to be protected. During introductions of new horses the effect of the animals' space allowances on the aggressiveness within the group was even stronger than in basic social situations. All enclosure sizes had a significant influence on the level of aggressiveness, which became even more evident when only enclosure sizes below 10,000 $\mathrm{m}^{2}$ were considered. However, the difference in sampling procedure between basic social situations (i.e. continuous behaviour sampling of all group members) and the introduction situation (i.e. continuous focal sampling of behaviours displayed between the introduced animal and the group members) limits the comparability of the different situations. The aggression level during introductions may have been even higher than reported, as aggressions that were not directed towards the new animal were not recorded. Still, we emphasize the importance of providing animals with as much space as possible, especially when introducing new horses into the group (Fürst et al. 2006, Knubben et al. 2008), as the groups' aggression level declined with the increase of enclosure size even when enclosure sizes were above $10,000 \mathrm{~m}^{2}$.

Besides discussing the aggressiveness of horses in social housing we have to point out that group housing has significant welfare advantages for the horses (Christensen et al. 2002, Bourjade et al. 2008, Hoffmann et al. 2012), as well as positive effects on human-horse relationship and horse training (Rivera et al. 2002, Søndergaard and Ladewig 2004). Horses pastured in groups completed training procedures faster (Rivera et al. 2002), "passed" more training stages, and bit the trainer less often than horses housed singly in stalls (Søndergaard and Ladewig 2004). They learn how to interact with other individuals in social housing, which results in an increased attentiveness to the signals from others, including the trainer (Søndergaard and Ladewig 2004). Furthermore, it has been suggested that horses with full physical contact with conspecifics are even tempered and therefore safe to handle and to ride (Ladewig 2011). The beneficial effect of group housing on the horse's social behaviour highlights the impor- 
tance of advising horse and stable owners, as well as constructors of equine facilities to increase the benefits by reducing aggression in horse groups through allowing more than $331 \mathrm{~m}^{2}$ space per horse.

Finally, by the use of many but diverse horse groups, the study provides several advantages. First of all the authors generated a large sample size, and were able to use group means for comparisons and draw general conclusions. In previous case studies with small group sample sizes, individual horses could have biased the results strongly and, therefore, the general conclusion of the studies should be treated with caution. Constraints and possible inaccuracies of using individual animals compared to using group means for statistics have been discussed by Phillips (1998, 2000). Secondly, it is interesting in itself, that individual and group variables have not been found to affect the outcome of the present study. In fact, we detected a stable, significant dependency between the horses' behaviour and enclosure size despite of possibly confounding factors.

\section{Conclusion}

In the present study the logarithmic enclosure size had a significant effect on the behaviour of horses in basic social situations, but not the horse groups and the type of paddock. There was a stable, significant correlation between the available space for horses in group housing and their aggressiveness towards group members in both basic social situations and when new horses were introduced into the group. Aggressions among horses decreased with increasing enclosure sizes. Therefore the authors recommend horse and stable owners, as well as constructors of equine facilities to pay more attention to minimum enclosure sizes to reduce aggression and injury risk in group housed horses.

\section{Acknowledgments}

The authors thank Jürgen Heinze, Charlotte Hemelrijk and Ulrich Schnitzer for helpful suggestions, Knut Krueger and Klaus Stark for assistance with statistical analysis, and Henning Thies and Doris Pfaffinger for language corrections. We are grateful to all stable masters and horse owners for allowing us to observe their horses. The study was supported by an Excellence grant of the Universität Bayern e.V. and an HWP II grant of the University of Regensburg.

\section{References}

Andersen K. F. (1992) Size, design and interspecific interactions as restrictors of natural behaviour in multi-species exhibits. 1. Activity and intraspecific interactions of Plains zebra (Equus burchelli). Appl. Anim. Behav. Sci. 34, 157-174

BayernViewer (http://www.geodaten.bayern.de/BayernViewer/index. cgi)

Berger J. (1977) Organizational systems and dominance in feral horses in the Grand Canyon. Behav. Ecol. Sociobiol. 2, 131-146

Berger J. (1986) Wild horses of the Great Basin. University of Chicago Press, Chicago

BMELV, Bundesministerium für Ernährung, Landwirtschaft und Verbraucherschutz (Hrsg.) (2009) Leitlinien zur Beurteilung von Pferdehaltungen unter Tierschutzgesichtspunkten
Bouriade M., Moulinot M., Henry S., Richard-Yris M. A. and Hausberger M. (2008) Could adults be used to improve social skills of young horses, Equus caballus? Dev. Psychobiol. 50, 408-417

Briefer Freymond S., Briefer E. F., Niederhäusern R. V. and Bachmann I. (2013) Pattern of social interactions after group integration: a possibility to keep stallions in group. PLoS ONE 8:e54688

Cassinello J. and Pieters I. (2000) Multi-male captive groups of endangered dama gazelle: social rank, aggression, and enclosure effect. Zoo Biol. 19, 121-129

Christensen J. W., Ladewig J., Søndergaard E. and Malmkvist J. (2002) Effects of individual versus group stabling on social behaviour in domestic stallions. Appl. Anim. Behav. Sci. 75, 233-248

Christman M. C. and Leone E. H. (2007) Statistical aspects of the analysis of group size effects in confined animals. Appl. Anim. Behav. Sci. 103, 265-283

Connor R. C., Wells R. S., Mann J. and Read A. J. (2000) The bottlenose dolphin: Social relationships in a fission-fusion society. In: Mann J., Connor R. C., Tyack P. L., Whitehead H. (Eds) Cetacean societies: Field studies of dolphins and whales. University of Chicago Press, Chicago, pp 91-126

Cozzi A., Sighieri C., Gazzano A., Nicol C. J. and Baragli P. (2010) Post-conflict friendly reunion in a permanent group of horses (Equus caballus). Behav. Processes 85, 185-190

Derungs S., Fürst A., Hässig M. and Auer J. A. (2004) Frequency, consequences and clinical outcome of kick injuries in horses: 256 cases (1992-2000). Wien. Tierärztl. Mschr. 91, 114-119

Dyer F. C. (2000) Group movement and individual cognition: lessons from social insects. In: Boinski S., Garber P. A. (Eds) On the move: how and why animals move in groups. The University of Chicago Press, Chicago, pp 127-164

Estevez I., Andersen I. L. and Naevdal E. (2007) Group size, density and social dynamics in farm animals. Appl. Anim. Behav. Sci. 103, $185-204$

Feh C. (1999) Alliances and reproductive success in Camargue stallions. Anim. Behav. 57, 705-713

Feist J. D. and McCullough D. R. (1975) Reproduction in feral horses. J. Repro. Fert. Suppl. 23, 13-18

Feist J. D. and McCullough D. R. (1976) Behavior patterns and communication in feral horses. Z. Tierpsychol. 41, 337-371

Fürst A., Knubben J., Kurtz A., Aver J. and Stauffacher M. (2006) Group housing of horses: veterinary considerations with a focus on the prevention of bite and kick injuries. Pferdeheilkunde 22, $254-258$

Grogan E. H. and McDonnell S. M. (2005) Injuries and blemishes in a semiferal herd of ponies. J. Equine Vet. Sci. 25, 26-30

Hartmann E., Keeling L. J. and Rundgren M. (2011) Comparison of 3 methods for mixing unfamiliar horses (Equus caballus). J. Vet. Behav. 6, 39-49

Hartmann E., Søndergaard E. and Keeling L. J. (2012a) Identifying potential risk situations for humans when removing horses from groups. Appl. Anim. Behav. Sci. 136, 37-43

Hartmann E., Søndergaard E. and Keeling L. J. (2012b) Keeping horses in groups: a review. Appl. Anim. Behav. Sci. 136, 77-87

Hoffmann G., Wagels E., Kräft S., Goossens L., Ammon C., Georg H. and Feige K. (2012) Comparative study of horses in tie stalls, individual housing in boxes and group housing. Pferdeheilkunde 28, $702-709$

Hogan E. S., Houpt K. A. and Sweeny K. (1988) The effect of enclosure size on social interactions and daily activity patterns of the captive Asiatic Wild horse (Equus przewalskii). Appl. Anim. Behav. Sci. 21, 147-168

Jørgensen G. H. M. and Bøe K. E. (2007) A note on the effect of daily exercise and paddock size on the behaviour of domestic horses (Equus caballus). Appl. Anim. Behav. Sci. 107, 166-173

Jørgensen G. H. M., Borsheim L., Mejdell C. M., Søndergaard E. and Bøe K. E. (2009) Grouping horses according to gender - Effects on aggression, spacing and injuries. Appl. Anim. Behav. Sci. 120, 94-99

Kaseda Y., Ogawa H. and Khalil A. M. (1997) Causes of natal dispersal and emigration and their effects on harem formation in Misaki feral horses. Equine Vet. J. 29, 262-266 
Knubben J. M., Fürst A., Gygax L. and Stauffacher M. (2008) Bite and kick injuries in horses: Prevalence, risk factors and prevention. Equine Vet. J. 40, 219-223

Kondo S., Sekine J., Okubo M. and Asahida Y. (1989) The effect of group size and space allowance on the agonistic and spacing behaviour of cattle. Appl. Anim. Behav. Sci. 24, 127-135

Krueger K., Schneider G., Flauger B. and Heinze J. Dynamics of third-party intervention in male Przewalski horses. Submitted

Ladewig J. (2011) Human safety and horse welfare - two sides of the same coin. J. Vet. Behav. 6, 292-293

Leone E. H., Christman M. C., Douglass L. and Estevez I. (2010) Separating the impact of group size, density, and enclosure size on broiler movement and space use at a decreasing perimeter to area ratio. Behav. Processes 83, 16-22

Li C., Jiang Z., Tang S. and Zeng Y. (2007) Influence of enclosure size and animal density on fecal cortisol concentration and aggression in Père David's deer stags. Gen. Comp. Endocrinol. 151, 202-209

Linklater W. L. (1998) The social and spatial organization of horses. PhD thesis, Massey University, New Zealand

Luescher U. A., McKeown D. B. and Halip J. (1991) Reviewing the causes of obsessive-compulsive disorders in horses. Vet. Med. 86, 527-530

Martin P. and Bateson P. (2007) Measuring behaviour: an introductory guide. Cambridge University Press

McDonnell S. M. (2003) The Equid Ethogram: A Practical Field Guide to Horse Behavior. Eclipse Press, Lexington, Kentucky

McDonnell S. M. and Haviland J. C. S. (1995) Agonistic ethogram of the equid bachelor band. Appl. Anim. Behav. Sci. 43, 147-188

Menke C., Waiblinger S., Folsch D. W. and Wiepkema P. R. (1999) Social behaviour and injuries of horned cows in loose housing systems. Anim. Welf. 8, 243-258

Mills D. and Nankervis K. (1999) Equine Behaviour: Principles \& Practice. In: Mills D., Nankervis K. (Eds) Blackwell Science, Oxford, pp 1 10-137

Monard A.-M., Duncan P. and Boy V. (1996) The proximate mechanisms of natal dispersal in female horses. Behaviour 133, 1095-1124

Moss C. J. and Poole J. H. (1983) Relationships and social structure in African elephants. In: Hinde R. A. (Ed) Primate social relationships: an integrated approach. Blackwell Science Ltd

Phillips C. J. C. (1998) The use of individual dairy cows as replicates in statistical analysis of their behaviour at pasture. Letter to the editor. Appl. Anim. Behav. Sci. 60, 365-369

Phillips C. J. C. (2000) Further aspects of the use of individual animals as replicates in statistical analysis. Letter to the editor. Appl. Anim. Behav. Sci. 69, 85-88

Price E. O. and Wallach S. J. (1991) Effects of group size and the male-to-female-ratio on sexual performance and aggressive behaviour of bulls in serving capacity tests. J. Anim. Sci. 69, $1034-1040$
R Development Core Team (2009) R: A Language and Environment for Statistical Computing. Foundation for Statistical Computing, Vienna

Rivera E., Benjamin S., Nielsen B., Shelle J. and Zanella A. J. (2002) Behavioral and physiological responses of horses to initial training: the comparison between pastured versus stalled horses. Appl. Anim. Behav. Sci. 78, 235-252

Rubenstein D. I. (1986) Ecology and sociality in horses and zebras. In: Rubenstein D. I., Wrangham R. W. (Eds) Ecological aspects of social evolution. Princeton University Press, Princeton, NJ, pp 282-302

Rutberg A. T. (1990) Inter-group transfer in assateague pony mares. Anim. Behav. 40, 945-952

Rutberg A. T. and Keiper R. R. (1993) Proximate causes of natal dispersal in feral ponies: some sex differences. Anim. Behav. 46, 969-975

Schneider G. and Krueger K. (2012) Third-party interventions keep social partners from exchanging affiliative interactions with others. Anim. Behav. 83, 377-387

Schmidt M. and Lipson H. (2009) Distilling free-form natural laws from experimental data. Science 324, 81-85

Skiff E. (1982) The effect of enclosure design on social interactions and daily activity patterns of the captive Asiatic wild horse (Equus przewalskii). Thesis, University of Minnesota, 31 pp

Søndergaard E. and Ladewig J. (2004) Group housing exerts a positive effect on the behaviour of young horses during training. Appl. Anim. Behav. Sci. 87, 105-118

VanDierendonck M. C., de Vries H., Schilder M. B. H., Colenbrander B., Porhallsdóttir A. G. and Siguriónsdóttir H. (2009) Intervention in social behaviour in a herd of mares and geldings. Appl. Anim. Behav. Sci. 116, 67-73

Waring G. H. (1983) Horse Behaviour: The Behavioural Traits and Adaptations of Domestic and Wild Horses, Including Ponies. Noyes, Park Ridge, NJ

Weng R. C., Edwards S. A. and English P. R. (1998) Behaviour, social interactions and lesion scores of group-housed sows in relation to floor space allowance. Appl. Anim. Behav. Sci. 59, 307-316

Wilson E. O. (2000) Sociobiology: the new synthesis. Harvard University Press, Cambridge, MA

\author{
Dr. Birgit Flauger \\ Universität Hohenheim \\ Institut für Tierhaltung und Tierzüchtung \\ FG Verhaltensphysiologie landwirtschaftlicher Nutztiere \\ Garbenstr. 17 \\ 70599 Stuttgart \\ birgit.flauger@uni-hohenheim.de
}

